\title{
Regeneration - A Pragmatic Approach to Informal Settlement Development of Abesan Lagos, Nigeria
}

\author{
Omolabi Abimbola Olufemi", Adebayo Pauline W. \\ Discipline of Town and Regional Planning, School of Built Environment and Development Studies, University of KwaZulu-Natal, \\ Durban, South Africa
}

Copyright $(2018$ by authors, all rights reserved. Authors agree that this article remains permanently open access under the terms of the Creative Commons Attribution License 4.0 International License

\begin{abstract}
The paper observes that the ever increasing population demand new urban land for housing and that this phenomenon has resulted in unprecedented development challenge in Nigerian urban centres, Lagos inclusive. The paper notes that over the years, Lagos has witnessed rapid population growth that characterized its development and emergence into megacity with attendant pressure on land for the housing supply of low income group. The paper appraises the effects of the standard of housing quality in informal settlement on the well-being of residents of the study area. It conducted a survey of 200 households using a structured questionnaire as instrument of data collection. This is with a view to collecting information on household characteristics, housing condition and environmental quality conditions of the study area. The paper examines the relationship between the deteriorating environmental situation and quality of life of informal settlements inhabitants. The result indicated that $73.0 \%$ of respondents were low income earners, $53.5 \%$ of the respondents have lived in the area for more than 10 years and $45.6 \%$ of residents were satisfied with access to neighbourhood facilities. It asserts that despite the illegality, 'informal' process provides the means for low income earners to gain access to land and housing outside the legal framework and regulations that prescribe the way land ought to be acquired and developed. The paper uses the concepts of healthy city and habitability among others as theoretical underpinnings for achieving sustainable urban development contextually. Conclusively, the paper notes that the efforts of government to manage the housing need of the low income group through different approaches notwithstanding, the effort do not appear to match the housing need of the group. It therefore recommends regeneration option that is driven by community participation as a pragmatic approach towards a sustainable residential development of the settlement and enhanced quality of life for the inhabitants.
\end{abstract}

Keywords Habitability, Healthy City, Informal Settlement, Sustainable Development, Quality of Life and
Urban Renewal

\section{Introduction}

Informal settlement (IS) otherwise referred to as a shanty town or squatter settlement has been defined in various ways depending on the planning and legal framework of a country where it exists. For the purposes of this study, informal settlements are defined as residential buildings built on "planned" and "unplanned" areas which do not have formal planning approval. It could also be defined as the residential areas where majority of residents have no security vis-à-vis the land or dwellings they inhabit. Additionally, it is regarded as the neighbourhoods where housing and living conditions are appallingly lacking, or are cut off from basic services and city infrastructure [1]. They are characterized mostly by the low quality houses and the lack of inadequate infrastructure and social services. These notions synchronise with [2,3] perception of IS both as a problem and solution to housing needs in speedily growing cities of many developing countries such as Nigeria the settlements have been categorised into two types including the illegally occupied settlement and the illegally developed settlements.

It is noteworthy that illegal occupation of land by squatters is peculiar with government acquired land for various reasons including rapid rate of urbanisation. Indeed, in most cities of Africa, including Lagos, rapid urban growth is occurring in the face of economic stagnation or low economic growth, rising unemployment, financially weak municipal or local government authorities, poor governance, and the absence of coherent urban planning policy [4]. Under such conditions, structural adjustment, currency devaluation and state retrenchment, rapid urban growth has been an inevitable recipe for the mass production of slums and informal settlements [5]. This postulations concurred with [6] assertion that the land 
authority in Zanzibar town between 1980 and 1990 was overwhelmed by the ever increasing number of urban dwellers who wanted land for shelter to the extent that after failing to obtain planned and serviced plots, individuals opted to buying pieces of urban fringe crop land and developing them without bothering to look for planned plots as the open alternative existed.

The situation is not different from what operates in some selected African countries including, Nigeria, Kenya, Egypt, Zambia, Zimbabwe and South Africa among others where informal settlements provide shelter to the majority of the urban population. Judging from what is happening in Ijora Badia- Lagos, Nigeria; Kibera,-Nairobi, Kenya; Riyadh,-Alexandria, Egypt; George settlement in Lusaka-Zambia; Chimambahuyo- Harare, Zimbabwe; Alexandria-Johannesburg, South Africa. It is possible to say that In Africa, from Cairo to Cape Town millions of poor urban dwellers reside in informal settlement. Against this background, $[7,8]$ estimated that 166 million people or $73 \%$ of sub-Saharan Africa's urban population are currently residing in informal settlement.

There are many factors that could account for the proliferation of informal settlements in cities of many developing countries of the world. With particular reference to Nigeria, [9] posited that the single factor that has affected land market and hence land accessibility more than anything else is the Land Use Act of 1978. To this end, the operation of the Act has inadvertently resulted in two types of land markets including the formal land market through government agencies and informal land market operated by land owning families. Within the formal land market, it is possible to observe that allocation criteria are exclusionary and only a very small proportion of upper income earners seemingly had access to land.

Evidently, this substantiates the view that the regulatory framework governing the delivery of planned residential land in many other African countries including Nigeria may indeed facilitate the development of informal settlements through complex bureaucratic procedures that make access to land not only difficult for low income households but at a price that is unaffordable $[10,11]$. Given this scenario, it could be postulated that low-income households seeking to acquire land for housing would not like to go through the arduous task of land acquisition processing. Thus, under the existing conditions, the direct implication is that most prospective low-income families face several possible options including non-convectional construction of unauthorized housing on marginal land while violating restrictive standards and regulations. A situation that is aggravated by the household reliance on family labour and artisanal techniques for construction, due to non-availability of mortgage or any other subsidized finance. The resultant effect is development of informal settlement that is characterized by missing basic facilities, overcrowded habitation and overstretching of housing amenities.
Other related factors that aggravate proliferation of informal settlement include failure of government to pay compensation due to experience of shortage of financial resources, abandonment of project and incessant change in government personnel. These factors often times prevent government to put the lands acquired in public interest into use thereby making such land vulnerable for encroachment by illegal occupiers. Additionally, at the centre of informal sector is the issue of poverty. In developing countries cities, Lagos inclusive, land in the formal market remains expensive for the urban poor. There is a direct correlation between economic growth and poverty reduction. With an average of per capital of less than US\$200, the majority of the population can be categorised as poor. In a situation where the cost of purchase of 400 square metres ranges between US $\$ 4,000$ to US $\$ 5000$ depending on location, no low income earner has the capacity to purchase such. To this end, the only option left for the low income earners to meet their housing need is to rely on informal sometimes in an unplanned area where the cost of the land is reasonably affordable.

The relevance of this option in housing development for the low income group in particular is corroborated by a recent empirical observations in many cities of African countries which according to [12] revealed that informal land systems are effective enough in terms of the quantity delivered to be an alternative to formal urban land delivery system for the low income group. The reason is that the land system is less bureaucratic, more flexible than formal systems and more effective in reaching the poor. Contrastingly, it has been observed that their viability, sustainability and liveability raises a series of questions as the system produces poorly planned areas with insufficient basic services as in the case of Nigerian cities.

Rapid urbanisation has been observed to be a characteristic feature of development with the resultant effect of informal settlement in Nigeria due to the ill preparation of government for the consequences of urbanisation. This assertion corroborates [13] observation that the weaknesses of government planning controls results in haphazard development that creates disorderly and unhealthy urban environment in Nigeria cities that stimulated a number of renewal programme which aimed at improving the living conditions in these areas. Despite this effort, the informal sector constitutes an important channel of urban land delivery and housing as only $20-40 \%$ of the physical development in Nigerian cities is carried out with formal government approval.

The issue and implications of mode of acquisition becomes worrisome when residents of informal areas compare their housing conditions to similar kinds of housing in formal areas with a feeling that government apathy is unfair to their plight. To this end, living in bad conditions along with the feeling of being unfairly treated often lead to frustration of many people residing in informal areas with particular reference to the impact on 
their quality of life. However, from the perspective of the United Nation's expressed Article 25, of 1948 universal declaration on fundamental human rights as the right to a decent living, central to which is access to adequate housing, it will not be out of place to presume that informal settlements are the products of failed policies, bad governance, dysfunctional land markets and lack of political improper distribution of funds and improper management. In real sense, each of the failures tends to exacerbate the toll on people already burdened by poverty and constrains the enormous potential for human development that informal settlement offer as an alternative to homelessness.

This study argues that regeneration provides the significant intervention strategy that aims at improving the informal settlement that has remained a major challenge to sustainable urban development in Lagos. The paper is divided into eight sections. Section 1 introduces the research contextually. Section 2 presents the literature review and conceptual issues. Section 3 examines the research objectives and the research questions. In Section 4 the research approach and methodology was presented. Section 5 discusses the analysis and findings. Section 6 shows the summary of findings. While Section 7 focuses on the recommendation with policy implications and section 8 presents the study's conclusion.

\section{Literature Review and Conceptual Issues}

Housing supply shortage and the deterioration in the quality of the housing stock through ageing and lack of repair have become serious problems that need to be addressed in many developing countries. They are associated with informal settlement, leads to the evolution of what is now termed as illegal settlement which was blamed in the 1970s on the tendency of the private land to marginalize the poor [14]. In Nigeria, the deplorable quality of housing is reflected in the predominance of structurally un-sound and substandard houses in these areas, thereby compounding the housing needs of urban dwellers. The magnitude of housing needs in Nigeria is manifested in the number of households residing in substandard housing unit particularly in the informal settlement and slums area which is estimated at $75 \%$ [15]. Thus, it can be safely concluded that informal settlements emerged on the landscape of Nigerian urban centres as enduring feature of urbanization process.

The characteristics of informal settlement can be summarized under four different categories including; physical, economic social and legal. The physical aspects include poor building conditions, overcrowding, poor environmental missing sanitation facilities, structures in elemental maintenance, presence of thrash and rubbish, inadequate community facilities such as schools, play grounds, public water and sewage system as well as street and drainage facilities and adverse environmental influences. The economic side includes poverty, low income rate for the dwellers, illegal ways of increasing the resident's income through drug dealing. On the social side is stigmatization and low human dignity that is often associated with living in such residential area. Others are social exclusion, bad behaviour and limited background. The legal aspect of informal settlements discourse presupposes that the neighbourhoods are residential areas where inhabitants have no security of tenure vis-à-vis the land or dwellings they inhabit, with modalities ranging from squatting to informal rental housing that may not comply with current planning and building regulations [16]. The aftermath of all these include unhealthy conditions and poor quality of life for inhabitants.

The realization of the physical and socio-economic characteristics of informal settlers exacerbated by poverty dated as far back as the late $20^{\text {th }}$ century. In the same vein, proposals for solution to the problem of informal settlement find expression in such strategies as total clearance and relocation, self-help and social housing among others $[17,18]$. However, in a developing country such as Nigeria with available limited financial resources, aggravated by relatively low level of income, full scale clearance that involves a huge capital outlay will be inconceivable. This is in addition to the fact that notwithstanding the precarious condition of the existing properties in the informal settlement, the housing units still constitute valuable capital of the nation. Moreover, with particular reference to the more progressive social orientated government, the problem of affordability of rent in the new improved neighbourhood coupled with displacement of large number of the economically disadvantaged member of the community is unlikely to be acceptable as a suitable solution for the sustainable development of informal settlement. These factors combined together to make large scale clearance unacceptable for improving the quality of life of dwellers of such poor residential neighbourhood.

The inadequate preparation of the country for the outcome of the urbanization phenomenon suggests that the nation will face the problem of informal settlement for many years to come. Thus, any effort towards improving the housing quality of the inhabitants of the settlement will involve a comprehensive urban regeneration strategy that concerns a package of basic services geared at improving the housing quality and the well-being of the community. The literature on housing quality that is suitable for the assessment of neighbourhood sustainability revealed the commonly used indicators to include structural adequacy, neighbourhood quality, residents' perception of neighbourhood safety, level of public services provided, access to work and other amenities, room density and housing affordability [19]. The foregoing prepares the basis for the discourse on concepts of healthy city, housing habitability, community participation and inclusion which 
are relevant to sustainable development of informal settlement.

\section{Housing Habitability}

One feature that human beings have in common is their capacity to modify their environment and adapt their habitats according to their well-being, supported by knowledge and technical improvements. The term housing habitability has over the years, continued to evolve and become broadened in scope to the extent that its application in urban studies can be approached from different perspectives including legality, quality of life and housing systems among others. To this end, [20] notes that from a legal perspective, habitability considers the basic aspects or standards of a dwelling, that are regulated by law and recognized, as basic requirements for well-being. From the quality of life perspective, habitability considers the housing and environmental conditions that affect users' way of life positively. It is concerned with improved living conditions in housing environment and residents' satisfaction derived from preserving the environment through avoidance of demolition, clearance of illegal building and redevelopment by gentrification. It implies the understanding of housing habitability as adaptation and upgrading of existing houses with a view to meeting the current residents' needs for comfort, accessibility and functionality by providing basic infrastructure and facilities. The systems perspective of the concept in application to this study revolves around four interacting sub-systems (see figure 1). These sub-systems as observed by [21] include shelter which is the dwelling unit per se. the residential environment that consists of a place with physical and symbolic boundaries where people inhabit and interact socially and economically. The dwellers occupy the dwelling and the institutional framework that consists of the planning rules and regulations and the administrative framework that manages the people, the dwelling environment and maintains the dwelling structure.

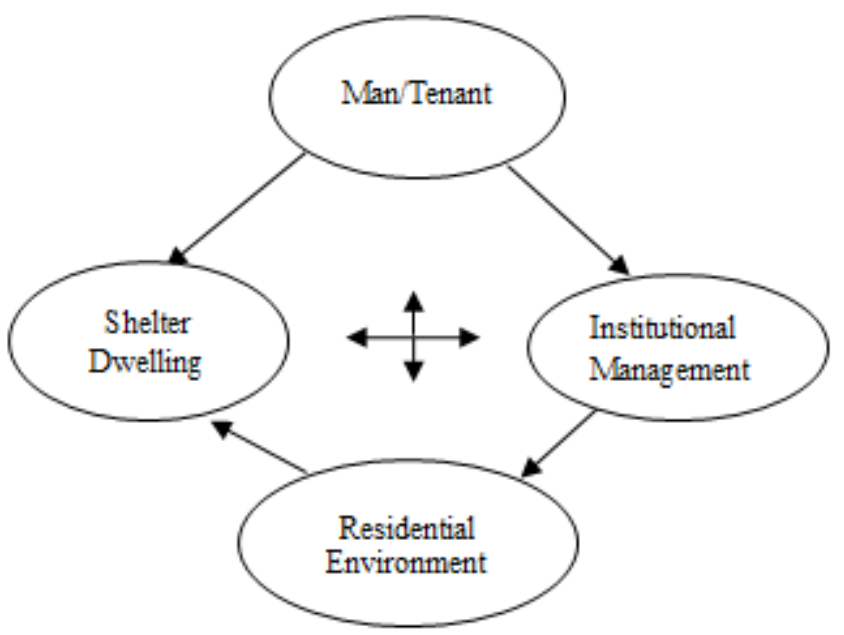

Figure 1. Conceptual Model of Habitability
The housing need influenced by the socio-economic factors of the dwellers must be met for an enhanced quality of life. The housing need implies consideration for shelter concerning such features as physical design and the functionality of the house, provision, availability, adequacy and functionality of the environmental facilities that include parking space, open space, good roads, recreational facilities, drainage and other amenities. The institutional management system refers to the planning rules and regulations that guide the administration of the community components. It consists of regulatory mechanisms such as development control, planning laws, planning standards, the building code, zoning regulations and the extent to which they are enforced to manage and maintain housing estates. The environmental sub-system emphasizes the role of physical planning in ascertaining the suitability of housing for human habitation based on planning standard. This reinforces the relevance of regeneration strategy for the sustainable development of informal settlements for an enhanced quality of life for dwellers.

\section{Healthy City}

Healthy city connotes an experiment that supposedly tackles health from a perspective that is not medical. It is not one that has achieved a particular health status. The concept does not have a universal definition. However, from the physical and social perspectives discourse, a healthy city can be described as one that is clean, safe, with good health and environmental services that promote safe and comfortable living of the people with their social bonds, beliefs, customs and lifestyles. Corroborating the postulation, [22] posits that a healthy city results from opportunities created in the built and social environments that promotes expansion of community resources in a manner that enables all its citizens to be active, mutually supporting each other in carrying out all functions of life and achieving their full potential through public policy implementation that brings to bear innovative actions for a sustainable human settlement development. It is based on the notion that both the physical and social environments affect quality of life in cities and the driving force in this regard is the recognition of regeneration of informal settlement as the primary mechanism through which sustainable neighbourhood development can be made out of informal area with a view to improving the living conditions of dwellers through provision of the missing community infrastructural facilities with minimum cost implication while embracing the public-private partnership strategy.

\section{Sustainable Housing Development}

Sustainable development as defined by the World Commission on Environment and Development in 1987 is development that meets the needs of the present generation 
without compromising the ability of future generations to meet their needs. Sustainable housing development is therefore no different to sustainable development and ought to be examined from a holistic perspective. An application of housing sustainability dimension within the sustainable human settlement discourse recognizes the fact that human settlements are like natural systems that are intrinsically susceptible to changes and degeneration. The implication is that if the primary concern of sustainable housing is to meet the accommodation needs of the citizens, the environment in the same vein is safeguarded from deteriorating to an extent that it diminishes the ability of future generations to meet their housing needs. Indeed, sustainable housing does not merely concern about meeting basic needs, but also improved habitability that transcends larger space and more facilities. It connotes shelter which is healthy, safe, affordable and secure, within a neighbourhood that is provided with piped water, sanitation, drainage, transport, health care, educational facilities and protected from environmental hazards [23]. The notion reifies the relevance of availability and functionality of infrastructural facilities provision in sustainable housing development. It has practical application to the study because of its concern to meeting people's needs as related to choice and control of their homes and neighbourhood which they value as where their social and cultural priorities are met towards improving their quality of life.

\section{Inclusionary Housing}

Inclusionary housing is described by [24] as a means of using planning system to create good housing condition that is affordable, habitable and sustainable. It refers to programme, law or regulation that requires or stimulates incentives to private developers, to engage in affordable or social housing as part of market driven housing development. In relation to informal settlement regeneration, it ensures the inclusion of informal settlement dwellers alongside other key urban stake holders in the planning, construction, operation and maintenance of projects it use. The participation by informal settlement dwellers is based on the belief that those who are affected by a decision have a right in the decision-making process; as concerned the technology being selected for its informal sector infrastructure development taking cognizance of the standard and regulation that the community can afford and maintain. The operational mechanism presupposes that towards ensuring wide coverage of infrastructure in the informal settlement, government should adopt the role of facilitator and enabler rather than provider. It emphasizes the need for public, private and partnership involvement in the regeneration of the informal settlement, as well as sharing of responsibilities between government and informal settlement dwellers rather than employing a traditional top down approach towards the regeneration of the settlement.

\section{Quality of Life}

Worldwide, issue of quality of life (QoL) is currently at the forefront of various fields of study which explains the reason while studies on it have drawn the attention of urban planners and policy makers. The opinion of [25] that QoL concept is fundamental to the overall satisfaction of citizens with living condition in a residential neighbourhood and monitoring public policies towards remedial actions when it is necessary. This notion reinforces the usefulness of QoL application to this study. There are many different interpretations of QoL term largely arising from its operational complexity and differences in scholars' backgrounds. The overall aim of QoL concept to this study hinges on the need to improve living conditions in residential neighbourhood in Lagos generally, and increasing the residential satisfaction level of inhabitants of informal settlement that is characterized by deficiencies in housing, poor physical, social and residential environment. This is in relation to access to a residential neighbourhod quality that is defined by availability and functionality of services and amenities within the geographic context.

\section{Urban Renewal}

The term urban renewal has several meanings. Since its introduction by American housing economist, Miles Colean, the definition has expanded in scope [26]. In its simplest form, it is defined as a deliberate effort to regenerate, make new again, restore, recover and transform an urban environment that is decayed or a human settlement that developed out of necessity but not in conformity with planning standard. More specifically, it is the process whereby old buildings or those that are in poor condition in part of a city are replaced or repaired, through structured, large-scale control to improve both the current and future operation of urban areas. The literature notes that through private and public activities, urban renewal can minimize living condition that is poor in residential area and deliberately change the urban environment. The conditions that qualify an urban area for renewal include inadequate housing, and dissatisfaction with housing by occupiers due to failure to meet housing needs derived from such conditions as informality. Situated in literature is a number of urban renewal strategies that range from comprehensive redevelopment, to gentrification, spot clearance, revitalisation, regeneration, rehabilitation, and legal enforcement and conservation with the sole aim of improving the living conditions of the poor residential neighbourhood [27]. This study adopts urban regeneration as a comprehensive and integrated vision and action that leads to the resolution of informality towards bringing a lasting improvement in the physical, economic and 
environmental conditions of a poor residential neighbourhood taking the legal component into consideration.

\section{Objectives and Research Questions}

The aim of the study is to improve the living conditions of informal settlements with a view to enhancing quality of life of dwellers. The objectives are: analysing the factors that account for the evolution of informal settlement in the study area, evaluating the significance of regeneration strategy as a mechanism of integrating informal settlement to the existing planned area and examining the policy implications of regeneration of informal settlement to sustainable urban development. The objectives tend to address the research questions that include viz; what are the factors that determine the evolution of informal settlements in urban areas of Nigeria as a developing country? what is the best interventionist approach to informal settlement upgrading? and what are the policy implications of informal settlements regeneration for a sustainable urban development?

\section{Research Approach and Methodology}

Lagos growing at an average rate of $7 \%$ per annum is one of the fastest growing mega cities in the world. One of the greatest challenges that have confronted the megacity is the inability of housing provision by government for such a massive population. To this end, the residents are compelled to provide housing for themselves using every means including building of illegal structures on land acquired for public interest in my many parts of Lagos. The study area is part of Alimosho which is the largest local government in Lagos with 1,288,714 inhabitants according to the official 2006 Census. However, the Lagos State Government disputes the official Census figures and claims a population within the local government area of more than two million residents.

A well-structured set of questionnaire, oral interview and field observation were used to collect basic data used for this study. In addition to option provided in an aspect of the questionnaire for data collection, respondents were asked to rate aspects of housing features as well as neigbourhood facilities quality based on a Likert scale with 5 representing very satisfied and 1 very dissatisfied. Secondary data was used from existing literature text books, journal, publications and other research works related to the study. The study area was divided into three zones and seven streets were randomly selected in each of the three zones. The survey was carried out purposely to elicit information on the personal characteristics of respondents. Additional information was collected on current and housing characteristics as well as access to neighbourhood facilities with a view to determining the relationship between housing characteristics and quality of life respondents. Ten questionnaires were randomly administered in each street making a total of 210 out of which 200 questionnaire were properly filled. This represents a response of $95.0 \%$.

\section{Analysis and Findings}

\section{Socio- Economic Characteristics of Respondents}

This section gives an indication of the breakdown of the socio-economic characteristics of the residents in the study area.

Table 1. Sex composition

\begin{tabular}{|c|c|c|}
\hline Sex & Frequency & Percent (\%) \\
\hline Male & 168 & 84.0 \\
\hline Female & 32 & 16.0 \\
\hline
\end{tabular}

Source: Field survey, 2014

The sex composition of the respondents indicated in table 1 showed that majority $84.0 \%$ of respondents were male, while $16.0 \%$ are female suggesting a proportion of male-headed households that is more dominated, confirming the expected role of man as bread winner and shelter provider for the family in the developing countries.

Table 2. Tenure ship

\begin{tabular}{|c|c|c|}
\hline Tenure ship & Frequency & Percent (\%) \\
\hline Renters & 112 & 56.0 \\
\hline Owners & 88 & 44.0 \\
\hline
\end{tabular}

Source Field Survey, 2014

Table 2 above revealed that $56.0 \%$ of the respondents are renters, while $44.0 \%$ are owners of the dwelling units occupied by them. It implies that the value of proportion of renters is slightly higher than the owner-occupier which is also a reflection of tenure ship trend in the formal settlement of all Nigerian cities.

Table 3. Age in Years

\begin{tabular}{|c|c|c|}
\hline Age in years & Frequency & Percent (\%) \\
\hline under 25 & 5 & 2.5 \\
\hline $26-35$ & 37 & 18.5 \\
\hline $36-45$ & 71 & 35.5 \\
\hline $46-55$ & 50 & 25.0 \\
\hline $56-65$ & 12 & 6.0 \\
\hline Above 65 & 25 & 12.5 \\
\hline Total & 200 & 100 \\
\hline
\end{tabular}

Source: Field survey, 2014 
The table showed that $21.0 \%$ of the respondents are less than 40 years old, while the age range 36-45years constitutes $35.5 \%$ and $42.5 \%$ constitutes respondents age that is above 45 years. The distribution appears to conform generally to the characteristic pattern of developing countries with high fertility levels and show young population that is active.

Table 4. Marital status

\begin{tabular}{|c|c|c|}
\hline Marital Status & Frequency & Percent (\%) \\
\hline Married & 160 & 80.0 \\
\hline Single & 15 & 7.5 \\
\hline Widow & 25 & 12.5 \\
\hline Total & 200 & 100 \\
\hline
\end{tabular}

Source: Field survey, 2014

Table 4 indicated $80.0 \%$ of the respondents are married, a low proportion of $7.5 \%$ of respondents are single, while $12.5 \%$ are widow. An analysis of the relationship between age and the marital status suggest a community that has tendency for natural multiplication.

Table 5. Educational status

\begin{tabular}{|c|c|c|}
\hline Education Status & Frequency & Percent (\%) \\
\hline None & 8 & 4.0 \\
\hline Primary school & 48 & 24.0 \\
\hline secondary & 102 & 51.0 \\
\hline Tertiary & 24 & 12.0 \\
\hline others & 18 & 9.0 \\
\hline Total & 200 & 100 \\
\hline
\end{tabular}

Source: Field survey, 2014

The educational status of the respondents is shown in table 5.It clearly showed that $4 \%$ had no formal education, $24.0 \%$ had primary education, $51.0 \%$ had secondary education, and $12 \%$ acquired tertiary education, while $9.0 \%$ had other forms of education. It revealed that secondary school as the highest level of educational attainment by the respondents. Level of education can influence the way the quality of an environment inhabited by an individual is perceived and rated.

Table 6. Household Size

\begin{tabular}{|c|c|c|}
\hline Household Size & Frequency & Percent (\%) \\
\hline One & 12 & 3.0 \\
\hline Two & 10 & 5.0 \\
\hline Three & 15 & 7.5 \\
\hline Four & 36 & 18.0 \\
\hline Five and above & 133 & 66.5 \\
\hline Total & 200 & 100 \\
\hline
\end{tabular}

Source: Author's field work, 2014

Table 6 indicates that over $66.5 \%$ of the respondents live in household of five or more persons living with their spouse, children and relatives. $18.0 \%$ consists of household with 4 persons. While $5.0 \%$ consists of two persons. The above indicates a household size that is moderate and tending higher than the national average household size of 5.0 persons.

Table 7. Occupational status

\begin{tabular}{|c|c|c|}
\hline Category & Frequency & Percent (\%) \\
\hline Public service & 63 & 31.5 \\
\hline Self employed & 47 & 23.5 \\
\hline Privately employed & 21 & 10.5 \\
\hline Unemployed & 31 & 15.5 \\
\hline retired & 38 & 19.0 \\
\hline Total & 200 & 100 \\
\hline
\end{tabular}

Source: Field survey 2014

Table 7 shows the occupational status of respondents $31.5 \%$ are government employed, $23.5 \%$ are self-employed especially in informal sector of economy including trading, transportation business, while $10.5 \%$ are privately employed as security personnel among others, $15.5 \%$ are unemployed, while $19.0 \%$ are retired. A further analysis showed that $29.7 \%$ of those who are employed in government sector are junior staff.

Table 8. Monthly income

\begin{tabular}{|c|c|c|}
\hline Monthly Income & Frequency & Percent $(\%)$ \\
\hline Less than $¥ 18,000$ & 102 & 51.0 \\
\hline$\$ 18,000-\$ 39,900$ & 45 & 22.5 \\
\hline$\$ 40,000-\$ 60,900$ & 40 & 20.0 \\
\hline$¥ 61,000-¥ 83,960$ & 6 & 3.0 \\
\hline$₫ 84,000-\$ 105,900$ & 5 & 2.5 \\
\hline Above $¥ 105,900$ & 2 & 1.0 \\
\hline Total & 200 & 100 \\
\hline
\end{tabular}

Source: Field survey, 2014

Table 8 depicts the household income of respondents and it reveals that $51.0 \%$ of the respondents earned very low income of less than N18, 000 per month. $22.5 \%$ proportion of the respondent's income earning is observed to fall within the tolerable low income level definition, and $20.0 \%$ earned moderate income. The subjective income categorization indicates that $5.5 \%$ earned medium income and only $1.0 \%$ could be considered as earning high income. It is instructive that $51.0 \%$ earned less than national minimum wage of $\mathrm{N} 18,000$.

Table 9. Length of Stay in buildings

\begin{tabular}{|c|c|c|}
\hline Duration of Stay in years & Frequency & Percent $(\%)$ \\
\hline $1-2$ & 11 & 5.5 \\
\hline $3-5$ & 21 & 10.5 \\
\hline $6-8$ & 28 & 14.0 \\
\hline $9-10$ & 33 & 16.5 \\
\hline Above 10 & 107 & 53.5 \\
\hline Total & 200 & 100 \\
\hline
\end{tabular}

Source; Field survey, 2014 
The question on length of stay was framed to enable dwellers the opportunity to assess the effect of the housing condition on their well-being. Table 9 indicated that more than half of the population $53.5 \%$ has lived in the housing unit occupied by them for more than 10 years. This suggests that the respondents have stayed long enough in the area for an objective assessment of the impact of the housing condition on their well-being.

\section{Housing Quality and Residential Environmental Characteristics}

The information on housing quality and neighbourhood environmental characteristics was collected with a view to assessing the extent to which the dwelling units erected by the settlers generally violated legal regulations as well as the most human minimal standards. A reliable assessment of existing housing characteristics would help formulate a framework for improving existing and new residential areas to meet future population increase.

Table 10. Age of buildings in years

\begin{tabular}{|c|c|c|}
\hline $\begin{array}{c}\text { Age of buildings in } \\
\text { years }\end{array}$ & Frequency & Percent (\%) \\
\hline Less than 10 & 7 & 3.5 \\
\hline $11-20$ & 61 & 30.5 \\
\hline $21-30$ & 105 & 52.5 \\
\hline $31-40$ & 22 & 11.0 \\
\hline Above 40 & 5 & 2.5 \\
\hline Total & 200 & 100 \\
\hline
\end{tabular}

Source: Field Survey, 2014

Table 10 indicated that only $3.5 \%$ of the buildings are less than 10 years. $30.5 \%$ of the buildings inhabited by the respondents were built between 11 and 20 years ago, while the building built between 21 and 30 years ago constitutes $52.5 \%$ of the dwelling units inhabited by the respondents. Whereas, buildings constructed over 30 years ago accounted for $13.5 \%$ of the housing units occupied by the respondents. The data showed that most of the buildings are old, explaining the observed nature of disrepair in the residential neighbourhood.

Table 11. Type of Dwellings

\begin{tabular}{|c|c|c|}
\hline Type of Dwellings & Frequency & Percent $\%$ \\
\hline Brazilian Type & 150 & 75.0 \\
\hline Flat & 42 & 21.0 \\
\hline Duplex & 8 & 4.0 \\
\hline Total & 200 & 100 \\
\hline
\end{tabular}

Source: Author's Field survey

Table 11 portrayed the result of type of dwellings units that are common in the study area. The survey revealed that
$75 \%$ of the buildings are the Brazilian types, while $21.0 \%$ are flats and only $4.0 \%$ are duplexes. The inference from the data indicates that the area is dominated by bungalow which influenced the high housing density nature observed in the community. The type of dwelling occupies by an individual has the tendency to influence the wellbeing of the occupier. It could be inferred that the dominance of the Brazilian type of dwelling promotes lack of privacy.

Table 12. Respondent's rating of housing facilities

\begin{tabular}{|c|c|c|c|c|}
\hline $\begin{array}{c}\text { Availability } \\
\text { of Housing } \\
\text { Facilities }\end{array}$ & Satisfied & Neutral & Dissatisfied & Total \\
\hline Water & $\begin{array}{c}71 \\
(35.5 \%)\end{array}$ & $28(14.0 \%)$ & $\begin{array}{c}101 \\
(50.5 \%)\end{array}$ & $\begin{array}{c}200 \\
(100 \%)\end{array}$ \\
\hline Kitchen & $\begin{array}{c}65 \\
(32.5 \%)\end{array}$ & $28(14.0)$ & $\begin{array}{c}107 \\
(53.5 \%)\end{array}$ & $\begin{array}{c}200 \\
(100 \%)\end{array}$ \\
\hline Toilet & $55(27.5)$ & $43(22.5 \%)$ & $\begin{array}{c}102 \\
(51.0 \%)\end{array}$ & $\begin{array}{c}200 \\
(100 \%)\end{array}$ \\
\hline
\end{tabular}

Source: Field Survey, 2014

Table 12 gives assessment of the facilities available in the dwelling units. In terms of water supply, a minority proportion of $35.5 \%$ of those interviewed were satisfied with the availability of the water, while $14.0 \%$ and $50.5 \%$ of the respondents respectively are neutral and dissatisfied with the available water facilities. The dissatisfaction hinges on lack of availability and the taste and odour of water. This explains the use of alternative sources of water supply including water vendors and rain to meet the domestic need of the respondents. Other facilities assessed revealed a similar trend with kitchen and toilet facilities. The respondent's proportions of dissatisfaction value regarding these facilities are $53.5 \%$ and $51.0 \%$ respectively. The rating on dissatisfaction hinges the fact that house occupiers have to improvise for the use of these facilities. Inference that can be deduced from this analysis is that many healthy problems can be linked to water availability, quality, accessibility and provision for domestic use. Improvised facilities used instead of standard kitchen and toilet can pose a major health hazard to the public.

Table 13. Respondent's rating of housing condition

\begin{tabular}{|c|c|c|}
\hline Housing Condition & Frequency & Percent (\%) \\
\hline Satisfied & 51 & 25.5 \\
\hline Neutral & 37 & 18.5 \\
\hline Dissatisfied & 112 & 56.0 \\
\hline Total & 200 & 100 \\
\hline
\end{tabular}

Source: Field survey, 2014

Table 13 depicted that an insignificant proportion of $25.5 \%$ of respondents were satisfied with the building conditions and $56.0 \%$ were dissatisfied with the housing condition. Rating was based on the construction materials and housing standard in terms of planning regulation. Poor house condition can pose a threat to the quality of life of occupiers. 
Table 14. Respondent's rating of access to neighbourhood facilities

\begin{tabular}{|c|c|c|c|c|}
\hline Access to Neighbourhood facilities & Satisfied & Neutral & Dissatisfied & Total \\
\hline Medical facility & $80(40.0 \%)$ & $30(15.0 \%)$ & $90(45.0 \%)$ & $200(100 \%)$ \\
\hline School & $50(25.0 \%)$ & $15(7.5 \%)$ & $135(67.5 \%)$ & $200(100 \%)$ \\
\hline Employment & $70(35.0 \%)$ & $23(11.5 \%)$ & $107(53.5 \%)$ & $200(100 \%)$ \\
\hline Security & $120(60.0 \%)$ & $30(15.0 \%)$ & $50(25.0 \%)$ & $200(100 \%)$ \\
\hline Recreation facility & $63(31.5 \%)$ & $29(14.5 \%)$ & $108(54.0 \%)$ & $200(100 \%)$ \\
\hline Shopping facilities & $121(60.5 \%)$ & $33(16.5 \%)$ & $46(23.0 \%)$ & $200(100 \%)$ \\
\hline Waste disposal & $130(65.0 \%)$ & $10(5.0 \%)$ & $60(30.0 \%)$ & $200(100 \%)$ \\
\hline Road & $89(44.5 \%)$ & $7(3.5 \%)$ & $104(52.0 \%)$ & $200(100 \%)$ \\
\hline Drainage & $100(50.0 \%)$ & $30(15.0 \%)$ & $70(35.0 \%)$ & $200(100 \%)$ \\
\hline
\end{tabular}

Source: Field survey 2014

The rating of satisfaction or dissatisfaction level of respondents with access to neighbourhod facilities, is shown in table 14. A casual observation of the table revealed that $45.0 \%$ are not satisfied with the access to medical facilities, while $15.0 \%$ were neither sure of satisfaction or not, and $40.0 \%$ were satisfied. Their expression of dissatisfaction derives from the average distance respondents cover to access the facility. In terms of educational facilities, $67.5 \%$ of respondents were not satisfied, while $25.0 \%$ were satisfied; and only $7.5 \%$ were neutral. It was found out that over population in schools was the main cause of dissatisfaction. For employment opportunities, $35.0 \%$ were satisfied, $11.5 \%$ were neutral and while $53.5 \%$ were dissatisfied with access to employment. Absence of major government offices in the community and industrial activities are the main source of dissatisfaction, a situation that explains the proliferation of informal sector activities in the neighbourhood. Regarding the recreational facilities, $54.0 \%$ of the respondents were not satisfied with the facilities, while $14.5 \%$ were indifferent and $31.5 \%$ were satisfied. Respondent's dissatisfaction was based on lack of organized recreational facilities which tend to discourage social cohesion in the community. For the shopping facilities, $60.5 \%$ responded that they were satisfied, $16.5 \%$ were indifferent, and only $23.0 \%$ were dissatisfied. $65.0 \%$ of the respondents rated waste disposal facilities satisfactory. With respect to accessibility to good road, $44.5 \%$ were satisfied and indicated that the roads condition were good, $52.0 \%$ claimed they were not satisfied, they described the roads as narrow, without any road mapping signs and poor drainage facilities, only $3.5 \%$ were neutral.

The study's investigation conducted on mode of land acquisition by respondents indicated that $73.4 \%$ acquired by purchase, $12.6 \%$ was through government allocation and $1.7 \%$ claimed others. Respondents claim on the state of building approval for dwelling units revealed that the process is on-going for $67.5 \%$ proportion. $30.0 \%$ claimed they had building plan approval, while an insignificant proportion of $2.5 \%$ did not respond.

\section{Summary of Findings}

The composition of age bracket interestingly reflects the perception of what constitutes 'well-being' to the different age group. While the youth wanted organized recreational facilities, the elderly wanted availability of more medical facilities. The educational status of the respondents to a great extent determines the type of occupation they engage in. They are majorly secondary school certificate holders who are employed at the lower cadre of government work. Respondents are mainly low income earners who cannot afford housing rent in other areas of the city with better housing facilities. These factors seemingly influence the decision of respondents to live continually in the area without any plan to relocate to another area in the near future. The duration of stay in the neighbourhood tends to influence their perception to the quality of the environment inhabited by them as the respondents seemingly feel comfortable living in the neighbourhood. Household's size was found to be high which portrays a high density area with the possibility of a likely increase in the future. The high occupancy rate in the area has implication for pressure on the available facilities and well-being of people. On the other hand, makes more people available for community participation in urban renewal exercise. Most residents $53.5 \%$ have lived over 10 years in the neighbourhood, a period that is seemingly long enough in the settlement to know the aspect of residential neighbourhood that requires urgent upgrading priority.

Generally, about $48 \%$ claimed that they would have been happier, if they have better access to good neighbourhood facilities and infrastructural facilities. While access to better medical facilities is the priority for the older age bracket, the middle age bracket prefers availability of more schools in their neighbourhood and the youth preferred better recreation facilities.

Findings on the mode of land acquisition revealed that $73.4 \%$ got through purchase. The singular reason given by the respondent is the ease of acquiring land for developmental purpose under the operation of Land use Decree. Additionally, $67.5 \%$ of the respondents have the 
processing of their building approval on-going. On the other hand, majority of respondents that claimed they had approved plan for their building was able to produce convincing evidence including approved building plans, receipts of processing among others. This presents a good reason for a more holistic and pragmatic approach towards improving the living condition of the neighbourhood.

When asked about the willingness of respondents to participate in any strategy that will improve the living condition of their neighbourhood, $88.0 \%$ of the respondents claimed they are willing to participate in the renewal of their neighbourhood. The reason is based on the conviction that it would enhance their quality of life without being displaced. In addition, they claimed that the investments they have already made to their properties remain and enhanced, which is considered significantly better than relocating them to a costlier alternatives that are less acceptable to them. Other respondents that are unwilling to participate are concerned with the cost implication.

\section{Recommendation}

Against this background, the first recommendation regarding the improvement of the living conditions of informal settlement is to prevent further deterioration. The action that is required here entails a full recognition of the fact that in all cities of the world, two circuits that are independent exist including the formal which is located within the planned confines and the informal which is outside those confines. Besides, with the understanding that many of the inhabitants of this informal settlement erect their dwelling on land which they have no legal claim to, they are less willing to invest in such a dwelling. Therefore, it is recommended that the property owners are granted ownership right in a quick manner. This act will reinforce their confidence and induce their interest to invest in infrastructure.

Besides, government should continue to embrace the role of facilitator and enabler with a view to support what inhabitants do and to regulate such to the benefit of collective good. In this regard, as a way of improving the living condition of the neighbourhood, what is recommended here is that both the revitalisation of existing community infrastructural facilities and the creation of new ones must be left in the hands of the residents while the government and private sector offer technical and training assistance to the community. Doing so will encourage the community to develop taking cognizance of minimum standard and regulations as well as building technology that is affordable and sustainable.

There is the need to recognise that problems associated with urban growth have a spatial expression that can be identified within the geographic space. What is being recommended here is emphasis on the need to understand the appropriateness of neighbourhood planning where street layout, and distribution of commercial activities supports sustainability in such a way that allows the inhabitants the opportunity to participate in the appropriation, controlling, monitoring and management of public space. Youth's engagement in the environmental quality improvement task of the community is recommended.

Further recommendation hinges on need to adopt integrated regeneration approach. This requires a combination of infrastructural and socio-economic development in addressing the problem of informal settlement. In this regard is the need for the empowerment of the residents of the area in income generating activities. This will result in resident's capacity to participate fully in the provision of missing community facilities in a piecemeal manner within the neighbourhood. Emphasis is on the political will by the government through the availability of funds. This can be in form of Social Development Fund' that will offer credits and micro credits for the residents towards the establishment of small business that will promote revenue generation. Additionally, there is a need for the understanding that through partnership between private sectors, donor agencies, civil society organization, and charity, a sound coordination among the stakeholders is seeing as the necessary intervention in such a way that community can build locally, operate, revitalise and maintain to acceptable town levels.

\section{Conclusions}

The study established that informal settlements are a reality in Nigeria, which as a developing country has to cope with. This is particularly with regard to Lagos that is experiencing a rapid rate of urbanization resulting in the changing status to a megacity. It created the opportunity of identifying various problems associated with evolution of informal settlement which precedes development in our major centres. The study revealed the fact that informal settlements are characterized by physical and socio-economic conditions that are adverse to good quality of life of residents and are therefore not sustainable. Within the Lagos State context, government had made several efforts to control and manage the growth of informal settlements. The strategies adopted include preparation of hierarchy of physical plans ranging from regional master plan to neighbourhood development plan, use of growth pole and corridor concepts in the future expansion of the city and total clearance of the most blighted areas and spot upgrading in neighbourhood development plan. Despite all efforts to control the growth of informal settlements, not much has been achieved in solving the challenge posed by the menace. The reason is that the various strategies adopted heretofore seem to have relied on the existing 
centralised planning methodology which isolated citizens from an aspect that affects their well-being. There is a need for paradigm shift in the approach to solve problems posed by informal settlements. In this regard, informal settlements ought not to be seeing as worse places within the urban system. Rather they should be seeing as playing complementary role to the overall growth of the cities in Nigeria as a developing country, providing shelter to millions of poor urban dwellers who have the right to city living but cannot access adequate housing through formal channels. To this end, the informal settlements are real, and appropriate handling of the problem requires a lot of political will and financial commitment on the part of government. Since the resources available to government for the provision of essential facilities are limited, government should explore the possibility of public private partnership initiative between government bodies, private sector and community organization, non-government organizations. This is more so, when people are their masters of their own destiny. Indeed, participation will not be meaningful if the people involved have no control over decisions taken by the organization to which they belong.

\section{REFERENCES}

[1] UN- Habitat 2016, Habitat III Issues Papers 22-Informal Settlement, New York, 31 May, 2015.

[2] Srinivas, H. 2005 'Urban Squatters and Slums Defining Squatter Settlements' Retrieved on December 2, 2009 from www/gdrc.org/uem/squatters/squatters.html.

[3] Bello, O. 2009, ' Squatter Settlement, Accessibility of Land and the Urban Poor' Paper Presented at FIG Working Week , Surveyors Key role in Accelerated Development, Eliat, Israel, 3-8 May, 2009.

[4] Annez, P., Buckley, R., and Kalarickal, J. 2010, African urbanization as flight? Some policy implications of geography, Urban Forum, 21 (3), pp. 221-233.

[5] Davis, M. 2004, Planet of slums: Urban involution and the informal proletariat, New Left Review 26, pp. 5-34. http://www.newleftreview.net/NLR26001.shtml

[6] Cole, 1993, National Land Use Plan; Appraisal: Analysis of Potentials and Issues (NLUP S.02); Zanzibar.

[7] Matov, G. 2000, 'Upgrading urban low-income settlements in Africa: Constraints, Potentials and Policy Options' Regional Roundtable on Upgrading Low-Income Settlements Johannesburg, South Africa October 3-5 2000.

[8] Wekesa, B.W., Steyn, G.S. and Otieno, 2011, 'A review of physical and Socio-economic Characteristics and Intervention approaches of informal settlements' Habitat International, 35 (2011), pp.238-245.

[9] Omirin, M.M., Nubi, T., Gbenga and Fawehinmi, S.A. 2003, (eds) Land Management and Property Tax Reform in Nigeria. Proceedings of National Workshop; organized by
Department of Estate Management, University of Lagos. pp. 71-84. Original 10.

[10] Kironde, J. M. L. 2006, 'The regulatory framework, unplanned development and urban poverty: Findings from Dar es Salaam, Tanzania', Land Use Policy, 23, pp. 460-472.

[11] Menshawy, A.E, Aly, S. S. and Salman, A.M. 2011, "Sustainable upgrading of informal settlements in the developing world, case study: Ezzbet, Abd El Meniem Riyadh, Alexandria, Egypt" Procedia Engineering, 21, (2011), pp. 168-177.

[12] Mattingly, M. and Durand-Lasserve, A. 2004, Sticking with tradition. How effective are new customary land delivery systems? ID 21 Insights Issue 48.

[13] Nwaka, G.I. 2005, 'The Urban Informal Sector In Nigeria: Towards Economic Development, Environmental Health, and Social Harmony' Global Urban Development Magazine. Vol.1 Issue 1.

[14] Turner, J. 1980, 'Housing Priorities, Settlement Patterns, and Urban Development in Modernizing Countries' AIP Journal November, pp. 354-363.

[15] Nubi T.O and Omirin. M.M 2006, Urban Violence, Land Rights and the Environment, Paper presented at International Conference on Environmental Economics and Conflict Resolution, University of Lagos

Ogunshakin, L. and Olayiwola, L. 1992, 'The collapse of official housing policy in Nigeria'. Habitat International 16 (1), pp. 41-53.

[16] Ajayi, B 2013,(ed) 'Urban Regeneration' in Perspectives on Urban and Regional Planning in Nigeria; A collection of Papers and Speeches Penthouse publications (Nig).

[17] Wegelin, E.A. 2004, 'Informal settlements and their upgrading: building on the lessons of three decades of experience' in Ministerial conference on informal settlements in South Eastern Europe, Vienna, 28 September and 01 October, 2.

[18] UN-HABITAT 2005, 'Bringing down the cost: realistic standards for shelter.' http://www.unhabitat.org.

[19] Okewole, I.A. and Aribigbola,A. 2006, Innovations and sustainability in housing policy conception and implementation in Nigeria in I.A. Okweole, A, Ajayi A, Daramola, K Odusanmi, O. Ogunba (eds): the Built Environment. Innovation Policy and sustainable Development, Ota Ogun State Nigeria Covenant University.

[20] Usobiaga, E. 2014, 'Design of an indicator system for habitability monitoring in the historical city of San Gabriel (Ecuador).' Tecnalia Research \& Innovation, Bilbao, Spain World, SB4 Barcelona, 28-30, October 2014.

[21] Thonetth, E.O. 2014, Housing development in Riverine Areas of Nigeria: The Habitability Concept. Omniscriptum $\mathrm{GmbH} \&$ Co KG Deutschland Germany.

[22] Edwards, P. and Tsouros, A.D. 2008, A healthy city is an active. A physical activity planning guides WHO. Europe.

[23] Chiu, R.L.H. 1999, "Housing, environment and the community", in: Hills, P. and Chan, C. (eds.), Community 
Mobilisation and the Environment in Hong Kong, pp. 139-160.

[24] Calavita, N. and Mallach, A. eds. 2010. Housing, social inclusion and land value recapture. Vern. Inc. Press Massachusetts.

[25] Sedaghatnia, S., Lamit, H., Ghahramanpouri, A. and Mohamad, S.Bt. 2013, 'An evaluation of resident's quality of life through neighbourhood satisfaction in Malaysia',
Environmental Management and Sustainable Development, 2 (1), pp.114-125.

[26] Hoffman, A.V. 2008, 'The lost history of urban renewal', Journal of Urbanism, 1 (3), pp. 281-301.

[27] Mckinnish, T., Walsh, R. and White, T.K.2010, 'Who gentrifies low-income neighbourhoods', Journal of Urban Economics, (67), pp.180-193. 